\title{
FORMATION AND ORGANIZATION OF THE INFORMATION AND LOGISTICS SYSTEM OF THE SHIPBUILDING CLUSTER
}

\author{
Iryna Zaporozhets \\ Candidate of Technical Sciences, Associate Professor, \\ Admiral Makarov National University of Shipbuilding, Ukraine \\ e-mail: iryna.zaporozhets@nuos.edu.ua,orcid.org/0000-0003-4015-5958
}

\section{Antonina Trushliakova}

Candidate of Economic Sciences, Associate Professor, Admiral Makarov National University of Shipbuilding, Ukraine e-mail: antonina.trushliakova21@gmail.com,orcid.org/0000-0003-1958-3472

\section{Summary}

The aim of the article is to develop the mechanisms of the information and logistics system of enterprises and organizations engaged in the design, construction, operation of transport vessels in order to maintain competitive positions on the inland waterways of Ukraine and in the river transport system of the European Union. The organization and functioning of the cluster has a positive impact on the search for consensus with all participants in river transport. The strategic guidelines of the cluster have been formed, where the participants combine resources to achieve the goals. An analysis has been carried out, which made it possible to determine the prerequisites for the creation of a national cluster of shipbuilding and ship repair. The functional and structural interaction of enterprises included in the business cluster for the construction and operation of transport ships has been developed. The basis for the organization of financial infrastructure is the creation of a specialized leasing company. The basis of the information and logistics system of the shipbuilding cluster is the production process, which is formed by the features of project-oriented production. The enterprises included in the business cluster are offered to describe business processes through reengineering mechanisms using the methodology of functional and structural modeling of logistics business processes, create a centralized electronic database and a single information network. The corporate information system combines the resources of a business cluster on the basis of a single information space.

Keywords: business cluster, logistics business processes, value chain, leasing, reengineering, corporate information system.

DOI: https://doi.org/10.23856/4920

\section{Introduction}

For Ukrainian shipbuilding enterprises, the relevance of cluster integration processes and the search for new forms of cooperation is due to the restoration of navigation on inland waterways and preservation of competitive positions in international transport and logistics processes.

In countries with developed economy, experience has been gained in creating economic cluster systems. Using the effect of clusters, enterprises are intensively developing due to cooperation, where there is a joint use of a knowledge base, financial resources, technologies, transport and logistics centers, and means of production. The purpose of the organization and 
functioning of the shipbuilding cluster system is to ensure the competitiveness of shipbuilding enterprises, development of effective mechanisms for their participation in international macrological systems for the design, construction and operation of transport vessels.

The use of logistics models and mechanisms in the management of the processes of creation and operation of shipbuilding cluster systems is determined by the presence in the cluster system of many flow processes and related information flows. The shipbuilding cluster system is a stable interaction of independent participants who implement information and logistics support of the full cycle of main and related flows, whose efforts are aimed at end-toend optimization of resources at all stages of project implementation.

Cooperation of cluster members is logistical integration. The cluster, as a logistics system, unites all participants in the logistics chain on the path to value creation, from ordering a shipping company to ship scrapping. The cluster solves the problems of optimizing flow processes and increasing efficiency through the synergy of not an individual participant, but the system as a whole. The potential for economic development of cluster structures along with competition is logistics. The functioning of the business cluster for the design, construction and operation of transport ships, in fact, means its logistics (Kolobov, 2008).

The possibility of forming other cluster integrations depends on the intensity of development of the shipbuilding cluster. The shipbuilding cluster is stringing associated production facilities, logistics and information centers on the logistics chain, and the development of the regional economy is proceeding as it should.

Within the logistical approach, shipbuilding cluster integration is a system of flows of both material and information. Logistics cluster management is the management of the movement of material and information flows in space and time from the moment of signing the contract for the implementation of the project to the delivery of the vessel to the customer. The implementation of the clustering mechanism is possible through information technology, and the development of logistics concepts is carried out through the continuous improvement of information software. In the shipbuilding cluster system, the information flow is generated by the initial material flow in the logistics system between the links of the logistics system and the external environment.

\section{Functional and structural interaction of the shipbuilding cluster system}

The business cluster for the construction and operation of transport vessels is a voluntary network horizontal association of enterprises and organizations engaged in the design, construction and operation of transport vessels. Cluster members combine efforts and resources to achieve such goals.

1. Design and construction of transport vessels that are competitive on the inland waterways of Ukraine and in the river transport system of the European Union.

2. Organization of efficient operation of the fleet on the inland waterways of Ukraine.

3. Development and implementation of modern logistics technologies.

4. Formation of new enterprises and jobs in the cluster structure, as well as outside the cluster map.

5. Creation of conditions for long-term interaction with local authorities through projects of industrial and technology parks.

6. Introduction of modern mechanisms of interaction with institutions of the financial and credit sphere of Ukraine and European financial institutions. 
7. Ensuring the competitive advantages for cluster members and the cluster as a whole due to stable and developed cluster connections, the presence of a long-term strategy for cluster integration.

8. Maintaining sustainable links in the value chain at all stages of the vehicle life cycle.

9. Expansion of opportunities for access to innovations and new technological solutions, including the organization of technology transfer, incubation of small innovative companies and projects.

10. Formation of new competencies and output of the cluster products into high-tech sectors.

The purpose of the cluster integration reflects its strategy and forms the basis of organizational mechanisms, Fig. 1.

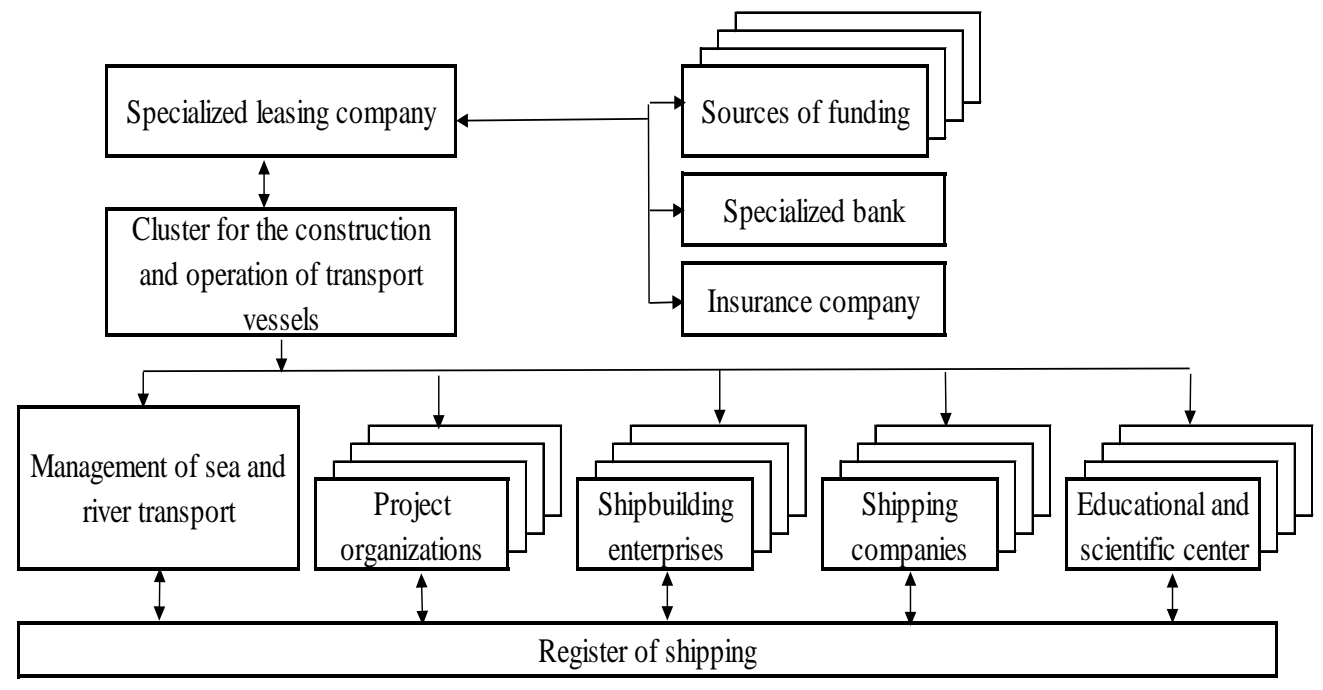

Fig. 1. Information model of the shipbuilding cluster system

In the Ukrainian shipbuilding, the prerequisites for the creation of a national cluster of shipbuilding and ship repair have been preserved, namely:

1. The presence of the main links in the chain for creation of the final cost of shipbuilding and ship repair products. At the PJSC Mykolaiv shipyard "Ocean", a block of hull shops, a dry dock, a floating dock, a horizontal slipway for building medium-tonnage vessels are in working order. The Nibulon shipyard has implemented a full cycle of construction of barges for the Dnieper and Southern Bug rivers, as well as a tug fleet. Kherson and Mykolaiv shipyards (part of Smart Maritime Group) are updating their business strategy. Design and engineering organizations Marine Engineering Bureau (Odessa) and MDEM (Mykolaiv) are actively working in international markets, mastering modern computer technologies for ship design.

2. Availability of a reliable network of suppliers of metal for the construction of ship hulls (Mariupol, Zaporizhzhia).

3. The unconditional interest of the regional authorities in the processes of exit of shipbuilding enterprises and organizations from the crisis state for the sustainable development of the regions.

4. Admiral Makarov National University of Shipbuilding (Mykolaiv) has preserved and develops the training of highly qualified personnel in all shipbuilding specialties, participates in international scientific programs of shipbuilding development. 
The cluster financial infrastructure base is proposed to be implemented through a specialized leasing company. The acquisition of vessels under the leasing scheme brings both organizational benefits to the shipping company (there is no need to independently register a sale and purchase transaction, register a vessel in the register of vessels, etc.) and economic (there is no need to use the entire amount of the vessel value in the process at the same time). Leasing mechanisms certainly contribute to attracting foreign capital for the development of the inland water transport system. The logistics infrastructure of the shipbuilding cluster includes everything that contributes to the material, financial, labor and institutional flow in the economy. The logistics infrastructure includes: transport facilities of enterprises, warehouses, suppliers of materials, components, information centers, financial institutions, insurance companies, customs terminals, etc. (Denysenko, 2010).

The basis of cluster integration is the production process, which is presented in Fig. 2 and has the form of functional and structural interaction of enterprises for the design, construction and operation of the project of construction and operation of a transport vessel (Fateev, 2014).

\begin{tabular}{|c|}
\hline $\begin{array}{l}1 \text { Marketing analysis of the transport } \\
\text { shipbuilding markets }\end{array}$ \\
\hline $\begin{array}{l}2 \text { Development of classification projects of } \\
\text { vessels }\end{array}$ \\
\hline 3 Development of technical projects \\
\hline $\begin{array}{l}4 \text { Determination of shipbuilding enterprises, } \\
\text { preparation of contracts for shipbuilding }\end{array}$ \\
\hline $\begin{array}{l}5 \text { Development of a working project taking into } \\
\text { account the specifics of the enterprise }\end{array}$ \\
\hline 6 Technological preparation of production \\
\hline $\begin{array}{l}7 \text { Ordering materials, components and their } \\
\text { delivery }\end{array}$ \\
\hline 8 Manufacturing of ship hull parts \\
\hline $\begin{array}{l}9 \text { Manufacturing of units and sections of the } \\
\text { hull. }\end{array}$ \\
\hline $\begin{array}{l}10 \text { Assembly of blocks on the pre-construction } \\
\text { site }\end{array}$ \\
\hline $\begin{array}{l}11 \text { Formation of the vessel's hull at the } \\
\text { construction site }\end{array}$ \\
\hline 12 Vessel's hull launching \\
\hline $\begin{array}{l}13 \text { Completion of the vessel, tests in the building } \\
\text { berth }\end{array}$ \\
\hline 14 Mooring and sea trials \\
\hline 15 Delivery of the vessel to the customer \\
\hline $\begin{array}{l}16 \text { Improvement of mechanisms and tools of } \\
\text { management in shipbuilding }\end{array}$ \\
\hline $\begin{array}{l}17 \text { Research work aimed at improving the } \\
\text { technology and organization of shipbuilding }\end{array}$ \\
\hline
\end{tabular}

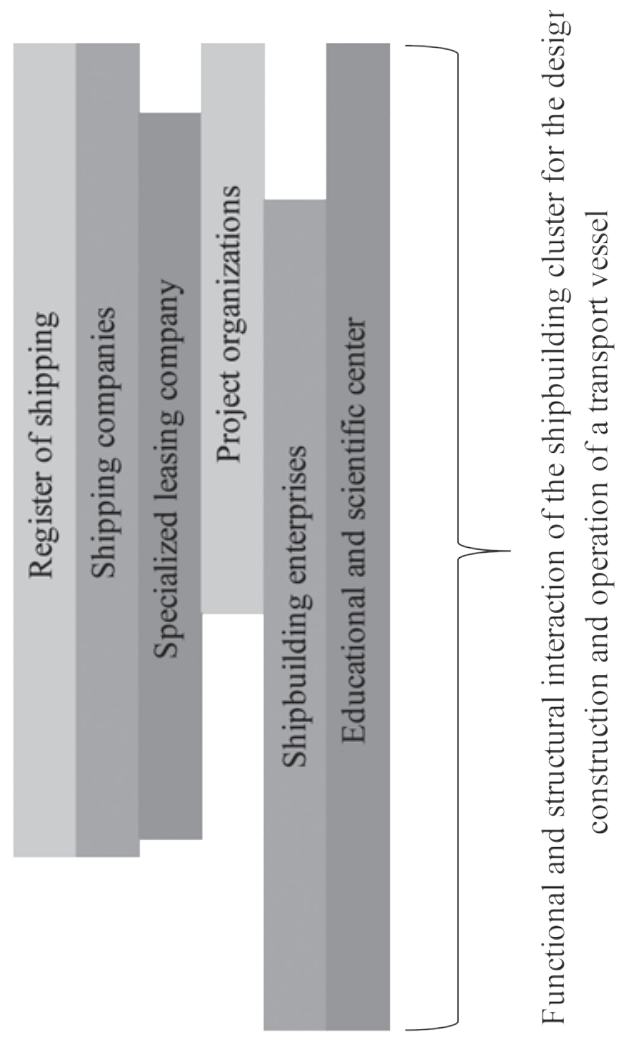

\section{Fig. 2. Scheme of functional and structural interaction of the shipbuilding cluster}

The information and logistics support of the cluster is formed by the peculiarities of the production structure of enterprises, which are as follows: project-oriented production, a significant amount of information links, contracting, supply of materials, leasing and other financing schemes (Hutorov, 2011). Shipbuilding projects are implemented by creating a resource flow management 
system in conjunction with the information flow. At the 1-3 stages, the parameters of the logistics system are being formed, the project cost chain with the main input information data is being planned. Stage 4 is the main one in the selection of a focus enterprise, selected by the method of expert assessments. From the 5th stage, the production process is implemented, which begins: from the rationing of material and labor resources for each planning and accounting unit, technical and economic indicators for each package of work are determined.

The shipbuilding industry is characterized by an uneven resource flow. The products of shipbuilding enterprises are designed for a specific customer and do not require special implementation mechanisms. Each project is an individual order and requires the appropriate resource component, which is laid down in the pre-investment phase and involved in the investment one. The cost of the vessel consists of step-by-step payments for the partial readiness of the work performed. Financial resources are used to search for and purchase material, which later become production inventories. Inventories take part in the implementation of the project and gradually go into work in progress and only over time become finished products. The transfer of financial resources to material ones occurs during the implementation of the project. Resources are determined by the time spent on the implementation of one cycle. The cycle of circulation of resources includes three stages: procurement, production, marketing. At shipbuilding enterprises, the longest production stage is with the use of all types of resources: financial, material, labor (Zaporozhets, 2021).

Internal logistics processes include logistical preparation of production, which is a set of all interconnected processes and ensures the implementation of existing business processes in the enterprise with the necessary components, materials in accordance with the project plan, volume and timing of work. The main purpose of logistics of the enterprise is the timely provision of the production process with the necessary resources. The resource component is the basis for the implementation of projects of shipbuilding enterprises.

The information flow permeates the entire organizational structure of the cluster and thus forms an information and logistics model of the shipbuilding cluster system, combining functional and organizational flow.

3. Reengineering of logistics business processes. Classification and coding of material resources

For enterprises that are members of the cluster, where a variety of partnerships prevails, reengineering of logistics business processes provides a solution to the following tasks:

- determination of the optimal sequence for the implementation of logistics functions, allowing to reduce the time required to complete the work on the project;

- optimal use of resources in business processes to reduce production costs and ensure competitive value of the project product;

- determination of rational schemes of interaction with cluster partners;

- creation of business processes aimed at adapting to the needs of end users, production technologies, quality of customer service in a dynamic external environment.

Reengineering of logistics business processes closely interacts with information technologies, as without reengineering information technologies do not give results, and without information technologies reengineering is impossible (American National Standard, PMBOK Guide (2017). Reengineering of logistics business processes of enterprises is carried out in two stages: at the first stage, the description of business processes using the SADT methodology, their rethinking and creation of new competitive logistics business processes is carried out. At the second stage, information technology should be connected to the management of new logistics business processes. 
The result of the reengineering of business processes of the enterprises included in the cluster should be the alignment and adoption of a unified standard for the classification and coding of technical and economic information in the direction of the classification of products and materials. Classification is the division of a set of objects into elements according to their similarity, respectively, adopted uniform methods. Coding is an assignment of the code of the classification group or object of classification.

The constant increase in the information flow is a significant problem for the modern world. For the efficient operation of the shipbuilding cluster, it is necessary to classify information for the timely adoption of management decisions. Shipbuilding projects are voluminous in terms of nomenclature, so the creation of a single system of classification and coding in a single information space with continuous information support of the vessels' life cycle will allow cluster enterprises to form a single database.

In shipbuilding, where many flow processes, there is a classifier of products and materials. The latter includes a systematized set of codes and named groups of materials, built according to a hierarchical system of classification and sequential coding. The material resource code includes: $(\mathrm{XXXX})$ - group code, $(\mathrm{XXX})$ - subgroup code, $(\mathrm{XX})$ - characteristic code,

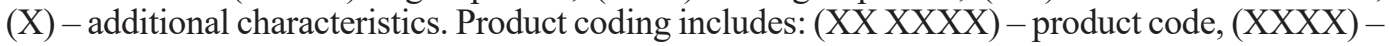
serial registration number, reflecting the type, brand, model, company that manufactures products.

Classifiers are the basis for creating own electronic database, which in a single information space will allow solving problems related to:

- design and technological preparation of production;

- calculation of project cost;

- formation of technological and planning and accounting documents;

- formation of production standard rates for materials.

Each enterprise that is a member of the cluster system uses a centralized electronic database, which operates in feedback on the codes that correspond to the data on the materials and the project as a whole.

\section{Organization of the information and logistics system of the shipbuilding cluster}

A corporate information system is an information system that supports the automation of cluster management functions and provides information for decision making. The structure of the information system of the shipbuilding cluster is based on the analysis of the functional model of the management system.

1. To solve typical functional tasks, the systems offered by the developers are selected. The list of information systems can include subsystems of own (unique) development, reflecting the features of the production structure of enterprises (Jesuthasan, 2020). The purpose of the development and implementation of automation tools for logistics functions at the enterprise is:

- improving the quality and efficiency of decision-making on planning, control of the resource flow;

- creation of a single information space that will ensure the effective distribution of information in the process of preparation and implementation of projects;

- coordination of the work for functional divisions of enterprises;

- accumulation of experience in planning and implementation of projects and application of information in the implementation of new projects.

The process of implementing the information system includes the following stages:

- inspection and reengineering of enterprises and development of implementation strategy is carried out by a group of experts and system analysts with the involvement of specialists of enterprises; 
- technical design of the information system is carried out by specialists in network technologies;

- introduction of separate systems is implemented by experts of firms of developers;

- filling of the system with data, adjustment to production conditions is carried out together with specialists of the enterprise of the firm by the developer;

- system integration and reengineering of logistics business processes is implemented by system integration specialists;

- staff training is performed by the developer;

- industrial operation of the system and its support and development.

Logistics functions are implemented through the flow of resources involved in the project. Shipbuilding companies use the local information system MS Project (Steiner Kristofer, 2018) to effectively manage projects, compile network schedules and track the progress of resource use and design work. Logistics tasks that are solved in the information system:

- development of a structural decomposition of works with the definition of a complete list of project works;

- formation of a list of resources and their assignment to the work of the project;

- building a network model of the project with the definition of the sequence of works and the establishment of links between operations;

- determination of resource calendars with the time of their use on the project;

- development of the project budget and determination of project funding;

- project monitoring using the earned value method.

This tool allows forming and managing project resources, as well as using this information to integrate resource flows into a single corporate complex for making management decisions at the level of both the enterprise and cluster.

The cluster association of enterprises uses a corporate network, the components of which are local information systems and embedded software products (Prohramne zabezpechennia dlia keruvannia proektamy, 2021), (Chto takoe ERP, 2021).The corporate information system combines cluster resources on the basis of a single information space.

\section{Conclusions}

1. Cluster integration is an effective mechanism of state support for the country's water transport system, an effective platform for implementing partnerships. The organization and functioning of the cluster has a positive effect on the search for consensus with all participants in the river transport market. Cluster integration creates conditions for attracting private investment in river transport.

2. Each enterprise included in the cluster must correspond to a single information and logistics space, through the solution of the following tasks: reengineering of logistics business processes, the result of which should be a competitive enterprise; development of a single standard for classification and coding of technical and economic information to create a single information space and database.

3. The basis of the corporate management system is the database, which ensures the interconnection of individual modules. The software is based on the MRP methodology (manufacturing resource planning), ERP (enterprise resource planning), PLM (product life cycle). The modular principle of constructing a cluster information system ensures the phased implementation and development of the system, taking into account the investment policy of a particular enterprise that is part of the cluster. 


\section{References}

1. Kolobov, A. A., Omelchenko, I. N., Orlov, A. I. (2008). Menedzhment vysokikh tekhnologiy [High technology management]. Moscow: Ekzamen. P. 621 [in Russian].

2. Fateev, N. V., Zaporozhets, I. M. (2014). Logisticheskoe upravlenie v sudostroitelnykh klasternykh sistemakh [Logistics management in shipbuilding cluster systems]. Mykolaiv: Zb. nauk. Pratz NUK, no. 3 (453), pp. 106-110 [in Russian].

3. Zaporozhets, I. M. (2021). Project management and logistics mechanisms in shipbuilding. Lublin: "KELM» (Knowledge, Education, Law, Management), no. 2(38), pp. 194-199.

4. Denysenko, M. P. (2010). Orhanizatsiia ta proektuvannia lohistychnykh system [Organization and design of logistics systems]. Kyiv: Tsentr uchbovoi literatury. P. 336 [in Ukrainian].

5. Hutorov, O. I., Lebedynska, O. I., Prozorova, N.V. (2011). Lohistyka: navch. posibnyk [Logistics: a textbook]. Kharkiv: Miskdruk. P. 322 [in Ukrainian].

6. American National Standard (2017). A Guide to the Project Management Body of Knowledge (PMBOK Guide). Sixth Edition. USA: ANSI/PMI. P. 976.

7. Ravin Jesuthasan, John Boudreau. (2020). Reinzhiniring biznesa. Kak gramotno vnedrit avtomatizatsiyu i iskusstvennyy intellekt [Business reengineering. How to intelligently implement automation and artificial intelligence]. Moscow: Alpina Publisher. P. 280 [in Russian].

8. Steiner Kristofer. (2018). Totalna avtomatyzatsiia. Yak kompiuterni alhorytmy zminiuiut svit [Total automation. How computer algorithms change the world]. Kyiv: Nash format. P. 280 [in Ukrainian].

9. Prohramne zabezpechennia dlia keruvannia proektamy. (2021). [Project management software]. Available at: https://www.microsoft.com/uk-ua/microsoft-365/project/projectmanagement-software

10. Chto takoe ERP? [What is ERP?]. (2021). Available at: https://www.sap.com/cis/insights/ what-is-erp.html 